Dhaka Univ. J. Biol. Sci. 24(2): 131-136, 2015 (July)

\title{
IMPACTS OF TILLAGE OPERATIONS AND MICROIRRIGATION PRACTICES ON WEED INFESTATION OF BRRI DHAN 28
}

\author{
S. Khatun, S.U. Ahmed*, S.M.A. Faiz and A.H.M. Mustafizur Rahmana \\ Department of Soil, Water and Environment, University of Dhaka, \\ Dhaka-1000, Bangladesh
}

Key words: Impact, Tillage operation, Microirrigation, Weed infestation, BRRI Dhan 28

\begin{abstract}
An experiment was conducted with BRRI dhan 28 following four irrigation treatments (flood, drip, alternate wetting and drying, sprinkler) and two tillage methods (conventional or puddled and unpuddled). Highest number of weed infestation over conventional tillage was observed when herbicide was not applied. Weed biomass was recorded maximum in sprinkler irrigation followed by alternate wetting and drying (AWD) and flood irrigation. The main type of weed in the rice field was sedges. Weed infestation at 20 and 40 days after herbicide application was found to be the highest due to sprinkler irrigation over AWD and flood irrigations. Unpuddled tillage showed lower weed number and biomass over the conventional puddle tillage.
\end{abstract}

\section{Introduction}

Weeds cause a persistent problem in rice fields since the beginning of settled agriculture. For Asia as a whole, weeds cause an estimated $10-15 \%$ reduction in rice yields equivalent to about 50 million tons of rough rice annually ${ }^{(1)}$. Weed infestation depends on the irrigation and cultural practices. In the irrigated boro rice crop, average yield loss due to weeds ranged from 0.2 to $0.7 \mathrm{t} / \mathrm{ha}$ depending on soil type in Bangladesh(2).

In lowland rice, approaches to conserve irrigation water, such as aerobic rice and alternate wetting and drying, may be adopted, but will have consequences for weed management ${ }^{(3,4)}$. Haden et al.(5) observed weed populations to shift with an increased incidence of sedges under reduced flooding regimes. Krupnik et al.(6) stated that where season-long flooding of lowland rice fields if replaced by only temporary flooding or aerobic conditions caused an increase in weed infestations.

Herbicide-based weed management is becoming a most popular method of weed control in rice. The advent of herbicide resistant species is an increasingly worrying problem for farmers, extension workers and policy-makers in many rice-producing areas. Therefore, the purpose of this study was to determine the influence of pre-rice cropping on weed infestation in low land rice.

*Author for correspondence: <shakil@du.ac.bd>. 


\section{Materials and Methods}

The experiment was conducted at the Research farm of Bangladesh Agricultural Research Institute in Gazipur. Four irrigation treatments, namely flood, drip, AWD and sprinkler irrigation and two tillage methods (puddled and unpuddled tillage) were applied on BRRI dhan 28.

The experiment was laid out in a RCBD with three replications. Block to block distance was $1 \mathrm{~m}$ and block size was $16 \mathrm{~m} \times 12 \mathrm{~m}$. The rice field was prepared and urea, TSP, MP, gypsum and $\mathrm{ZnSO}_{4}$ were applied at the rate of 333,130, 109, 78 and $8 \mathrm{~kg} / \mathrm{ha}$, respectively.

Five micro plots $(1 \mathrm{~m} \times 1 \mathrm{~m})$ were established in every block to see the weed infestation at different intervals (20 and 40 days) after pre-emergence herbicide (Refit, 1.2 1/ha) application. Insecticide Suntup $1.5625 \mathrm{~kg} / \mathrm{ha}$ was used to control disease. Weeding was done twice at 20 and 40 DAT.

\section{Results and Discussion}

Population of weeds varied widely due to variation in tillage operations and irrigation practices in the presence of herbicide (Table 1). Maximum number of weeds, namely sedge was observed in the plot under flooded condition $\left(233.33 / \mathrm{m}^{2}\right)$ followed by sprinkler $\left(204.17 / \mathrm{m}^{2}\right)$, drip $\left(170.83 / \mathrm{m}^{2}\right)$, and AWD $\left(166.67 / \mathrm{m}^{2}\right)$ irrigation at 20 days after plantation in the puddled field (Table 1). In contrast, in unpuddled field, the situation was changed where the highest number of sedge was accounted in sprinkler irrigated plot $\left(191.67 / \mathrm{m}^{2}\right)$ and the number decreased to $104.17 / \mathrm{m}^{2}$ in flooded plot. The number, however, remained intermediate, between these two, ranking 120.83 and $108.33 / \mathrm{m}^{2}$ due to AWD and drip irrigations, respectively.

Table 1. Effect of tillage and irrigation on number of weeds in presence of herbicide.

\begin{tabular}{|c|c|c|c|c|c|c|c|}
\hline \multirow{3}{*}{$\begin{array}{l}\text { Tillage } \\
\text { practice }\end{array}$} & \multirow{3}{*}{$\begin{array}{l}\text { Irrigation } \\
\text { method }\end{array}$} & \multicolumn{6}{|c|}{ Weed number $\left(/ \mathrm{m}^{2}\right)$} \\
\hline & & \multicolumn{3}{|c|}{20 days } & \multicolumn{3}{|c|}{40 days } \\
\hline & & Sedges & Broad leaf & Grass & Sedges & Broad leaf & Grass \\
\hline \multirow[t]{4}{*}{ Puddled } & Flood & 233.33 & - & - & 325.00 & - & - \\
\hline & Drip & 170.83 & - & - & 370.83 & 25.00 & - \\
\hline & AWD & 166.67 & - & - & 529.17 & - & - \\
\hline & Sprinkler & 204.17 & - & - & 383.33 & - & - \\
\hline \multirow[t]{4}{*}{ Unpuddled } & Flood & 104.17 & - & - & 295.83 & - & - \\
\hline & Drip & 108.33 & 37.50 & - & 395.83 & - & - \\
\hline & AWD & 120.83 & 8.33 & - & 220.83 & - & 41.67 \\
\hline & Sprinkler & 191.67 & 8.33 & - & 366.67 & 8.33 & - \\
\hline
\end{tabular}

After 40 days of transplantation, the maximum number of sedges were recorded in plots where AWD $\left(529.17 / \mathrm{m}^{2}\right)$ and drip $\left(395.83 / \mathrm{m}^{2}\right)$ irrigation were applied in puddled 
and unpuddled fields, respectively (Table 1). The population of sedge increased markedly at 40 days in comparison to 20 days. It can be noted that the difference in population of sedges were very close where sprinkler $\left(383.33 / \mathrm{m}^{2}\right)$ and drip $\left(370.83 / \mathrm{m}^{2}\right)$ irrigation in puddled field were applied. Their number $\left(366.67 / \mathrm{m}^{2}\right)$ did not also vary too much when sprinkler irrigation was supplied in unpuddled field. Broad leaf weeds were accounted only in unpuddled plots at 20 DAT ranging from 8.33 to $37.50 / \mathrm{m}^{2}$. The efficiency of herbicide to control broad leaf weeds in AWD and sprinkler irrigation plots were found to be equal in unpuddled field. Abundance of broad leaf weeds were found only in drip irrigated plot while in rest of the irrigated plots no trace of broad leaf weeds and grass were enumerated at 20 DAT. Similar trend in broad leaf weeds and grass was also observed at 40 DAT except in puddled plot where drip (6 broad leaf $/ \mathrm{m}^{2}$ ) and sprinkler $\left(8.33 / \mathrm{m}^{2}\right)$ irrigations were applied. Presence of grass was accounted $\left(41.67 / \mathrm{m}^{2}\right)$ in unpuddled and puddled fields following AWD irrigation with no change at $40 \mathrm{DAT}$. It is evident that herbicide became effective to kill the broad leaf weeds completely with the generation of grass $\left(41.67 / \mathrm{m}^{2}\right)$ at 40 DAT in unpuddled field. However, their limited appearance $\left(25 / \mathrm{m}^{2}\right)$ occurred in puddled field following drip irrigation.

Weed infestation increased in the puddle than unpuddled condition was observed by many scientists $(3,4)$, requiring more crop management skills and better access to production resources. Hand-weeding requirements may increase by up to $35 \%$ with temporary rather than permanent flooding in lowland systems(6). Roy et al.(7) reported the effects of green growth regulator (GGR-6) and herbicides on weed infestation and yield performance of boro rice (cv. Iratom-24) in direct seeding method and got the positive effect on weed infestation and yield performance. Similarly, in Malaysia, Thailand, and Philippines, herbicides have been used widely to control weeds pre-planting in rice fields ${ }^{(8)}$.

Maximum number of weeds, namely sedge was observed in the plot under AWD $\left(504.16 / \mathrm{m}^{2}\right)$ irrigation followed by sprinkler $\left(462.5 / \mathrm{m}^{2}\right)$, flooded $\left(395.83 / \mathrm{m}^{2}\right)$ and drip $\left(358.33 / \mathrm{m}^{2}\right)$ irrigation at 20 DAT in the puddled field without herbicide (Table 2). In contrast, in unpuddled field, the highest number of sedge was accounted in sprinkler irrigated plot $\left(374.06 / \mathrm{m}^{2}\right)$ and the number decreased to $233.33 / \mathrm{m}^{2}$ in flooded plot. The number, however, remained intermediate, between these two, ranking 437.5 and $366.66 / \mathrm{m}^{2}$ due to AWD and drip irrigation, respectively. In the puddle field, broad leaf was found only at AWD $\left(12.50 / \mathrm{m}^{2}\right)$ irrigation. However, the highest number of grass was found at sprinkler $\left(37.50 / \mathrm{m}^{2}\right)$ irrigated plot and that of the lowest at AWD $\left(8.33 / \mathrm{m}^{2)}\right.$ irrigated plot.

After 40 days of transplantation, the maximum number of sedges were recorded in sprinkler irrigated plot under both unpuddled $\left(820.83 / \mathrm{m}^{2}\right)$ and puddeld $\left(770.83 / \mathrm{m}^{2}\right)$ fields. The minimum number of sedges were recorded in drip irrigated plot under both puddle $\left(533.33 / \mathrm{m}^{2}\right)$ and unpuddeld $\left(437.50 / \mathrm{m}^{2}\right)$ fields. Broad leaf weeds were accounted 
only in unpuddled plots at 20 DAT ranging from 20.83 to $220.83 / \mathrm{m}^{2}$. In contrast, in puddled field, it is evident that puddle became active to kill the broad leaf weeds

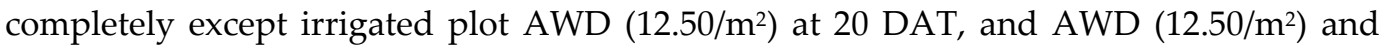
sprinkler irrigated plot $\left(4.16 / \mathrm{m}^{2}\right)$ at 40 DAT. However, limited appearance of grass occurred at 40 DAT when compared to 20 DAT (Table 2).

Table 2. Effect of tillage and irrigation on number of weeds in absence of herbicide.

\begin{tabular}{|c|c|c|c|c|c|c|c|}
\hline \multirow{3}{*}{$\begin{array}{l}\text { Tillage } \\
\text { practice }\end{array}$} & \multirow{3}{*}{$\begin{array}{l}\text { Irrigation } \\
\text { method }\end{array}$} & \multicolumn{6}{|c|}{ Weed number $\left(/ \mathrm{m}^{2}\right)$} \\
\hline & & \multicolumn{3}{|c|}{20 days } & \multicolumn{3}{|c|}{40 days } \\
\hline & & Sedges & Broad leaf & Grass & Sedges & Broad leaf & Grass \\
\hline \multirow[t]{4}{*}{ Puddled } & Flood & 395.83 & - & 17.50 & 570.83 & - & 8.33 \\
\hline & Drip & 358.33 & - & 12.50 & 533.33 & - & 4.16 \\
\hline & AWD & 504.16 & 12.50 & 8.33 & 650.00 & 12.50 & - \\
\hline & Sprinkler & 462.50 & - & 37.50 & 770.83 & 4.16 & - \\
\hline \multirow[t]{4}{*}{ Unpuddled } & Flood & 233.33 & 20.83 & 104.16 & 445.83 & - & 12.50 \\
\hline & Drip & 366.66 & 220.83 & 8.33 & 437.50 & 75.00 & - \\
\hline & AWD & 437.50 & 116.66 & 112.5 & 562.50 & 41.66 & - \\
\hline & Sprinkler & 374.06 & 95.83 & 25.00 & 820.83 & 116.66 & - \\
\hline
\end{tabular}

Table 3. Effect of tillage and irrigation on weed biomass in presence of herbicide.

\begin{tabular}{|c|c|c|c|c|c|c|c|}
\hline \multirow{3}{*}{$\begin{array}{l}\text { Tillage } \\
\text { practice }\end{array}$} & \multirow{3}{*}{$\begin{array}{l}\text { Irrigation } \\
\text { method }\end{array}$} & \multicolumn{6}{|c|}{ Weed biomass $\left(\mathrm{g} / \mathrm{m}^{2}\right)$} \\
\hline & & \multicolumn{3}{|c|}{20 days } & \multicolumn{3}{|c|}{40 days } \\
\hline & & Sedges & Broad leaf & Grass & Sedges & Broad leaf & Grass \\
\hline \multirow[t]{4}{*}{ Puddled } & Flood & 20.83 & - & - & 47.92 & - & - \\
\hline & Drip & 12.92 & - & - & 43.33 & 0.83 & - \\
\hline & AWD & 13.33 & - & - & 35.00 & - & - \\
\hline & Sprinkler & 13.75 & - & - & 30.83 & - & - \\
\hline \multirow[t]{4}{*}{ Unpuddled } & Flood & 12.92 & - & - & 19.17 & - & - \\
\hline & Drip & 10.83 & 2.50 & - & 40.00 & - & - \\
\hline & AWD & 12.92 & 1.25 & - & 18.33 & - & 16.66 \\
\hline & Sprinkler & 12.50 & 0.42 & - & 27.50 & 0.42 & - \\
\hline
\end{tabular}

Extreme weather may increase the risk of herbicides either causing crop damage or not being effective ${ }^{(9)}$. They suggested that use of more herbicide may cause harmful impact on the crop as well as the human being who consume the crops.

Maximum sedge weed biomass was observed at flood irrigation at both 20 and 40 DAT in the plot under puddled condition. Small differences of sedge biomass were found among the different irrigation plots $\left(10.83-12.92 \mathrm{~g} / \mathrm{m}^{2}\right)$ under unpuddled fields. At 20 DAT, only trace of broad leaf biomass was found under unpuddled fields (0.42-2.50 
$\left.\mathrm{g} / \mathrm{m}^{2}\right)$. However, they also appeared at 40 DAT in drip irrigation $\left(0.83 \mathrm{~g} / \mathrm{m}^{2}\right)$ under puddled and in sprinkler irrigation $\left(0.42 \mathrm{~g} / \mathrm{m}^{2}\right)$ under unpuddled plot. The sedge biomass increased markedly at 40 DAT in comparison to 20 DAT. The grass biomass $\left(16.66 \mathrm{~g} / \mathrm{m}^{2}\right)$ only found at 40 DAT in AWD irrigation under unpuddled field (Table 3).

The unpuddled condition showed the lowest average weed biomass in the rice plant over the puddle condition and the flood irrigation gave the highest average weed biomass of the rice plant over the other three irrigations. It must be due to the cultivation methods and the controlled supply of water at the growth stage of the rice plants.

Table 4. Effect of tillage and irrigation on weed biomass in absence of herbicide.

\begin{tabular}{|c|c|c|c|c|c|c|c|}
\hline \multirow{3}{*}{$\begin{array}{l}\text { Tillage } \\
\text { practice }\end{array}$} & \multirow{3}{*}{$\begin{array}{l}\text { Irrigation } \\
\text { method }\end{array}$} & \multicolumn{6}{|c|}{ Weed biomass $\left(\mathrm{g} / \mathrm{m}^{2}\right)$} \\
\hline & & \multicolumn{3}{|c|}{20 days } & \multicolumn{3}{|c|}{40 days } \\
\hline & & Sedges & Broad leaf & Grass & Sedges & Broad leaf & Grass \\
\hline \multirow[t]{4}{*}{ Puddled } & Flood & 85.00 & - & 65.00 & 97.08 & - & 4.16 \\
\hline & Drip & 70.00 & - & 5.42 & 77.92 & - & 5.00 \\
\hline & AWD & 161.25 & 0.42 & 12.50 & 99.16 & 0.42 & - \\
\hline & Sprinkler & 157.50 & - & 35.83 & 130.00 & 0.83 & - \\
\hline \multirow[t]{4}{*}{ Unpuddled } & Flood & 55.00 & 1.66 & 31.66 & 89.58 & - & 1.25 \\
\hline & Drip & 52.08 & 12.5 & 9.17 & 74.16 & 7.92 & - \\
\hline & AWD & 55.83 & 8.75 & 48.75 & 88.75 & 7.08 & - \\
\hline & Sprinkler & 82.92 & 10.83 & 27.50 & 128.33 & 7.08 & - \\
\hline
\end{tabular}

In the puddled condition at $20 \mathrm{DAT}$, sedge biomass was highest in AWD (161.25g $\left./ \mathrm{m}^{2}\right)$ irrigation followed by sprinkler $\left(157.50 \mathrm{~g} / \mathrm{m}^{2}\right)$, flood $\left(85 \mathrm{~g} / \mathrm{m}^{2}\right)$ and drip $\left(70 \mathrm{~g} / \mathrm{m}^{2}\right)$ irrigation. In the unpuddled condition at 20 DAT, maximum sedge biomass was observed in sprinkler $\left(82.92 \mathrm{~g} / \mathrm{m}^{2}\right)$ irrigation (Table 4). The number, however. remained very close $\left(55.83-52.08 \mathrm{~g} / \mathrm{m}^{2}\right)$ in other irrigated plots. At $40 \mathrm{DAT}$, the maximum sedge biomass was recorded in sprinkler irrigation under puddled $\left(130 \mathrm{~g} / \mathrm{m}^{2}\right)$ and unpuddled $\left(128.33 \mathrm{~g} / \mathrm{m}^{2}\right)$ fields. Whereas the lowest value of the same was found in drip irrigation under puddled $\left(77.92 \mathrm{~g} / \mathrm{m}^{2}\right)$ and unpuddled $\left(74.16 \mathrm{~g} / \mathrm{m}^{2}\right)$ fields. The unpuddled condition yielded the lowest average weed biomass in the rice field over the puddle condition. When the herbicide was not applied to the field, broad leaf grew comparatively higher $\left(1.66-12.50 \mathrm{~g} / \mathrm{m}^{2}\right)$ at the 20 DAT and suppressed at the 40 DAT $\left(0.0-7.92 \mathrm{~g} / \mathrm{m}^{2}\right)$.

Unpuddled tillage accounted lower weed number and weeds biomass over the conventional puddle for the drip, AWD and flood irrigation. The main type of weed in the rice field was sedges. But, the broad leaf and grasses increased in number when herbicide was not applied to the field. 


\section{References}

1. Naylor R 1996. Herbicides in Asian Rice: Transitions in weed management. Palo Alto (California): Institute for International Studies, Stanford University and Manila (Philippines): International Rice Research Institute. pp. 270.

2. David EJ 996. Weed management in small holder rice production in the tropics. Natural Resources Institute, Greenwich Cartham, Kent, UK. pp. 1-3.

3. Vries ME, J Rodenburg, BV Bado and KE Giller 2010. Rice production with les irrigation water is possible in a sahelian environment. Field Crops Research 116(1-2): 154-164.

4. Krupnik TJ, J Rodenburg, D Mbaye and VR Hade 2010.Trade-offs between rice yield, weed competition and water productivity in the Senegal river valley. pp. 2.3.1-2.3.9.

5. Haden VR, JM Duxbury, A DiTommaso and JE Losey 2007. Weed community dynamics in the system of rice intensification (SRI) and the efficacy of mechanical cultivation and competitive rice cultivars for weed control in Indonesia. J. Sustainable Agriculture 30(4): 5-26.

6. Latif MA, MR Islam, MY Ali and MA Saeque 2005. Validation of the system of rice intensification (SRI) in Bangladesh. Field Crops Res. 93(2-3): 281-292.

7. Roy HP, MA Salam, MR Islam, KU Ahammed and B Akhter 2009. Weed infestation and yield performance of boro rice in direct seeding method as influenced by green growth regulator and herbicides. Int. J. Sustain. Crop Prod. 4(1): 83-90.

8. Pingal P, M Hossain and RV Gerpacio 1997. Asian rice bowls: The returning crisis. IRRI, Manila, Philippines.

9. Patterson DT, JK Westbrook, RJV Joyce, PD Lingren and J Rogasik 1999. Weeds, insects and diseases. Climatic Change 43(4): 7. 